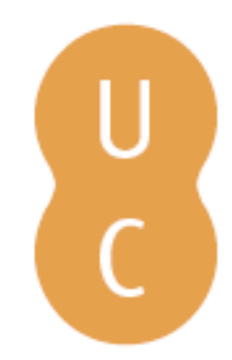

\title{
nommalina
}

\section{Problemas de ontem e de hoje que poderia voltar a discutir com o nosso amigo António Gama se...}

\author{
Autor(es): $\quad$ Mota, Júlio Marques \\ Publicado por: Imprensa da Universidade de Coimbra \\ URL \\ persistente: URI:http://hdl.handle.net/10316.2/43477 \\ DOI: $\quad$ DOI:978-989-26-1348-2; DOI:https://doi.org/10.14195/978-989-26-1343-
}

Accessed : $\quad$ 26-Apr-2023 14:47:54

A navegação consulta e descarregamento dos títulos inseridos nas Bibliotecas Digitais UC Digitalis, UC Pombalina e UC Impactum, pressupõem a aceitação plena e sem reservas dos Termos e Condições de Uso destas Bibliotecas Digitais, disponíveis em https://digitalis.uc.pt/pt-pt/termos.

Conforme exposto nos referidos Termos e Condições de Uso, o descarregamento de títulos de acesso restrito requer uma licença válida de autorização devendo o utilizador aceder ao(s) documento(s) a partir de um endereço de IP da instituição detentora da supramencionada licença.

Ao utilizador é apenas permitido o descarregamento para uso pessoal, pelo que o emprego do(s) título(s) descarregado(s) para outro fim, designadamente comercial, carece de autorização do respetivo autor ou editor da obra.

Na medida em que todas as obras da UC Digitalis se encontram protegidas pelo Código do Direito de Autor e Direitos Conexos e demais legislação aplicável, toda a cópia, parcial ou total, deste documento, nos casos em que é legalmente admitida, deverá conter ou fazer-se acompanhar por este aviso.

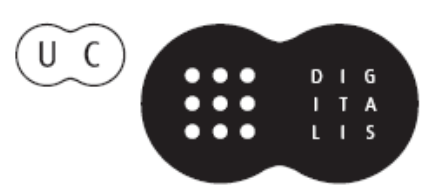




\section{FERNANDA CRAVIDÃO}

\section{IÚCIO CUNHA}

PAULA SANTANA

\section{NORBERTOSANTOS}

(ORG.)

\section{ESPAÇOS E TEMPOS EM GEOGRAFIA}

HOMENAGEM A ANTÓNIO GAMA

IMPRENISA DÁ UNIVERSIDADE DE COIMBRA COIMBRA UNIVERSITY PRESS

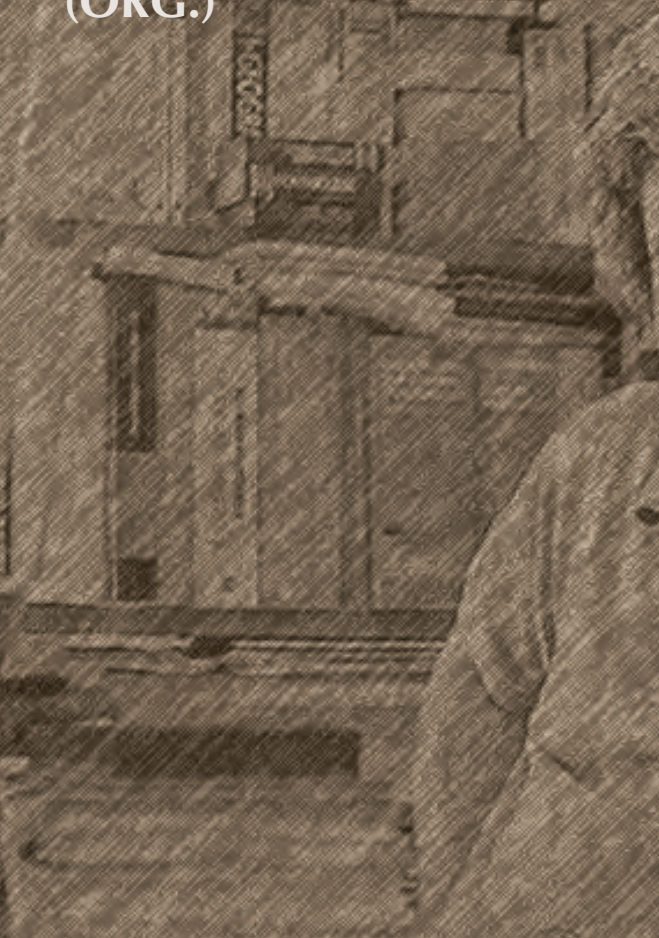




\section{PROBLEMAS DE ONTEM E DE HOJE QUE PODERIA VOLTAR A DISCUTIR \\ Com o nosso amigo António gama SE...}

Júlio Marques Mota/jmarquesmota@sapo.pt

\section{Introdução}

Fez dois anos que um nosso amigo morreu, o António Gama. Pediram-me um texto sobre uma temática ligada às privilegiadas por si na sua vida académica para um livro de homenagem. Não sou nem demógrafo nem geógrafo, sou economista mas, apesar disso, sinto uma enorme vontade de responder ao pedido, até porque escrevê-lo significa para mim realizar um desejo, o de me imaginar agora mesmo a analisar e a confrontar com o António Gama uma série de problemas atuais com os de outrora, se ele estivesse vivo. De imediato, lembro-me das palavras que escrevi no dia 31 de dezembro de 2014, dia da sua morte, no blogue A Viagem dos Argonautas:

Hoje, um amigo meu morreu. Um homem de uma estatura verdadeiramente fora do comum num meio onde muita gente se pensa como "de exceçáo" devido à nobreza garantida pelos seus "títulos", títulos que esse meu amigo não tinha. Mas tinha outros, seguramente.

Hoje, um amigo meu morreu. Um amigo que à Universidade conferiu e entregou todo ou quase todo o sentido da sua vida.

E da vivência em comum na Universidade relembro aqui dois momentos. O primeiro, a sua participação no Ciclo Integrado de Cinema Debates e 
Colóquios na FEUC, entre 2007 e 2012, em particular numa sessão onde se projetava Kisagany Diary, o mais dramático documentário que já vi. Relembro-o ao lado de Francisco Louçá, Pezarat Correia e Soares da Fonseca. E dessa sessão, com o auditório completamente cheio, relembro a sua leitura sobre os movimentos de populaçôes em África, um continente verdadeiramente à deriva, com deslocaçốes que nem a ONU queria reconhecer.

Há um enorme paralelo, num outro continente, no Camboja, onde a ordem de Nixon de bombardear este país foi transmitida por Kissinger aos generais com a indicação de dispararem sobre tudo o que mexe, sobre tudo o que voa ("Anything that flies on everything that moves").

O segundo, a sua participação na elaboraçáo de um caderno de textos sobre a China, sobre os left-behind, onde está incrustada a marca de um artista em migraçóes, em Geografia Humana.

Senti também os seus conhecimentos sobre fenómenos migratórios na Europa de Leste, na sessão sobre este tema. Também na sessão sobre grandes cidades em França e sobre o racismo nelas reinante, onde participou com Sami Nair e Joachim Becker. A propósito desta sessão, vale a pena relembrar um episódio que mostra a estatura de António Gama e a qualidade da nossa imprensa. Ele e eu propusemos a um dado jornalista que entrevistasse Sami Nair, um dos maiores especialistas sobre migraçôes na Europa e conselheiro de Estado em França. Sami Nair chegou a Coimbra pelas 14 horas e partiria às 5 horas da madrugada seguinte. Um esforço enorme para participar num debate em Coimbra.

Foi proposto ao jornalista o António Gama fazer as perguntas que ele, jornalista, colocaria a Sami Nair e acompanhá-lo na própria entrevista, um pouco como seu auxiliar e amigo. Naturalmente assim, porque o normal é pensar-se que um jornalista não seria especialista nestas matérias. Para o António Gama o que era importante era que Sami Nair esclarecesse o leitor português sobre uma série de questóes e problemas que a Europa atravessava e que estavam ligados à sua própria fragmentaçẫo pressentida num horizonte próximo, entâo, e onde os fenómenos das migraçóes em massa ganhavam já uma forte dimensão. A esta situação não é alheia a política externa dos Estados Unidos seguida por Madeleine Albright e cujos efeitos se fazem agora sentir com a instabilidade 
na Europa de Leste. Na véspera, o jornalista suspende o projeto da entrevista porque a agência para quem trabalhava não estava interessada no assunto. Foi pena! Perdeu-se a oportunidade de divulgar informação importante, de se ler um discurso impertinente e não se questionou assim a liberdade de imprensa. Como convinha ao sistema, fez-se a censura, por omissão, como agora se costuma dizer, como agora se costuma muito fazer.

Já é tempo de olhar um pouco por dentro de alguns dos problemas de ontem e de hoje que poderia voltar a discutir com o nosso amigo António Gama se...

\section{A decomposiçáo da Europa de Leste}

Recentemente li um artigo de Ahmed (2015), onde se pode ler:

Como o historiador britânico Mark Curtis descreve minuciosamente no seu livro sensacional, Secret Affairs: Britain's Collusion with Radical Islam, os governos dos Estados Unidos e do Reino Unido continuaram a apoiar secretamente redes filiadas na Al-Qaeda na Ásia Central e nos Balcãs depois da guerra fria, e pelas mesmas razóes que anteriormente, na sua luta contra a influência russa, e doravante chinesa, a fim de estender a hegemonia americana à economia capitalista mundial. A Arábia Saudita, primeira plataforma petrolífera do mundo, continuou a ser o intermediário desta estratégia anglo-americana irrefletida.

[Sobre a Bósnia], Curtis relata que um ano depois do atentado do World Trade Center de 1993, Osama bin Laden abriu um escritório no bairro de Wembley, em Londres, sob o nome de Advice and Reformation Committee, a partir do qual coordenou atividades extremistas no mundo inteiro.

Na mesma época, o Pentágono transportou por aviáo milhares de mujahedines da Al-Qaeda da Ásia Central para a Bósnia, violando assim o embargo de armas imposto pela ONU, de acordo com ficheiros dos serviços de informação holandeses. Estes combatentes eram acompanhados por forças especiais americanas. "O xeique cego", que foi condenado pelo atentado ao World Trade Center, 
estava implicado profundamente no recrutamento e no envio de combatentes de Al-Qaeda para este mesmo país.

[Quanto ao Afeganistão], sensivelmente desde 1994 até ao 11 de setembro, os serviços de informação militar dos Estados Unidos, Grā-Bretanha, Arábia Saudita e Paquistão, forneceram secretamente armas e fundos aos talibấs, que protegiam a Al-Qaeda.

Em 1997, a Amnistia Internacional lamentou a existência de relaçóes políticas estreitas entre a milícia talibã no país, que acabara de conquistar Cabul, e os Estados Unidos. O grupo de defesa dos direitos do homem fez referência a relatórios credíveis sobre as madraças frequentadas pelos talibãs no Paquistão, indicando que estas relaçóes podem ter sido estabelecidas mesmo no início do movimento talibá.

Estes relatórios provinham de Benazir Bhutto, então primeira-ministra do Paquistão; esta, hoje falecida, referiu que "as madraças tinham sido abertas pela Grã-Bretanha, Estados Unidos, Arábia Saudita e Paquistão no decorrer de Jihad, a resistência islâmica contra a ocupação do Afeganistão pelos soviéticos". Sob a tutela americana, a Arábia Saudita continuava a financiá-las...

[No Kosovo], Curtis refere que a NATO continuou a patrocinar as redes filiadas à Al-Qaeda neste país no final dos anos de 1990, quando as forças especiais americanas e britânicas forneceram armas e formaram os rebeldes do Exército de Libertaçáo do Kosovo (UÇK), entre os quais figuravam recrutamentos mujahedines. Estes efetivos contavam com uma célula rebelde dirigida por Mohammad al-Zawahiri, irmão do braço direito de Osama bin Laden, Ayman al-Zawahiri, que é hoje o líder de Al-Qaeda.

No mesmo período, Osama bin Laden e Ayman al-Zawahiri coordenaram os atentados de 1998 contra as embaixadas americanas no Quénia e na Tanzânia desde o escritório do primeiro em Londres.

Havia contudo algumas boas notícias: as intervençôes da NATO nos Balcâs, conjugadas com a desintegraçáo da Jugoslávia socialista, abriram a via à integração da regiấo na Europa ocidental, à privatizaçáo dos mercados locais e ao estabelecimento de novos regimes em prol do projeto de canalização trans-Balcãs, destinado a transportar o petróleo e o gás da Ásia Central para o Ocidente. 
Quando li isto fiquei boquiaberto a lembrar-me das longas conversas havidas com o António Gama quanto ao papel belicista da Administração Clinton no que diz respeito à desagregação da Europa de Leste e em particular ao papel de Madeleine Albrigth. Isto na altura em que estávamos a realizar o Ciclo de Cinema na FEUC. Lembro-me ainda hoje das críticas duríssimas que contra esta o António Gama tecia e exatamente pela sua política na Europa de Leste. Na época, isto para mim era uma novidade. Bill Clinton representava para mim a Esquerda e Madeleine Albrigth a sua representante na política externa. Hoje, sei que esta foi durante anos a advogada de diretor do fundo abutre Elliott Management: Paul Singer, o homem que quis confiscar os ativos da República do Congo, o homem que quis confiscar a Argentina, o homem que atacou a PT e o ex-BES com posiçóes de forte especulação a descoberto.

\section{Portugal, país de imigrantes}

Portugal é um país de imigrantes, de emigrantes, de trabalhadores "destacados”, dentro e fora. Portugal é portanto cruzado pelos fenómenos mais ou menos dramáticos que atravessam hoje toda a Europa. Um ou outro exemplo desta situação é o que relato a seguir a partir de uma crónica minha escrita em Faro, num certo verão.

Era sábado à tarde, quase todos os quiosques estavam fechados. À primeira vista, parecia que a desregulaçáo do mercado de trabalho iniciada de forma claramente neoliberal em 2004, com o governo de Durão Barroso, continuada pelo governo de José Sócrates e depois ampliada de forma violenta pelo governo de Passos Coelho não chegou ainda aqui. Poupa-se é no pessoal precário, sem contrato, é esta a melhor explicação que encontrei para ao sábado à tarde ou no domingo não poder facilmente comprar o jornal.

Vou entấo longe comprá-lo. Ao sair de casa, junto a uma das muitas clínicas que há por Faro, deparo-me com uma senhora a ouvir com atenção as indicaçóes que lhe estavam a dar. Pela cara de espanto percebia-se que pouco ou nada estava 
a entender do que lhe estava a ser explicado. Despreocupadamente, dirijo-me à senhora e pergunto-lhe para onde queria ir. "Para a central de camionagem, queria ir para Albufeira", diz-me.

Disse-lhe para me acompanhar, já que eu ia para o mesmo sítio. Aceitou. Era uma senhora elegante, forte, vestida de modo muito simples, de saia escura e blusa branca. Roupa simples, nada cara, mas elegantemente utilizada. Meto conversa e pergunto de que país era. "Da Rússia. Venho da Rússia. Vim como turista, paguei, fiquei". Olho, com algum espanto, sinto o aspeto frontal da resposta, ouço a frase curta, vejo-lhe a franqueza espelhada na cara. Uma "generala", pensei. Uma "generala" de outras paradas militares, claramente era o que o seu andar anunciava. Criou-se entáo uma espécie de solidariedade, uma abertura a perguntas que imediatamente não deixei de fazer. "Como veio?"

Como turista terá vindo, pagou, quer dizer que por detrás havia uma organizaçáo, havia pessoas a cobrar $10 \%$ a $15 \%$ dos rendimentos mensais a auferir por estes migrantes, os "Al Capones" da fragmentada ex-União Soviética. Sobre isto nada pergunto, como é natural. O espaço de Schengen, a ideia de livre circulação de pessoas à escala da Europa, ao ser protegido pelos países participantes com uma peneira sem rede, permitiu uma massa brutal de migração clandestina, barata, a servir de base para a reproduçâo do capitalismo vigente, de matriz neoliberal. Mas este tema ultrapassa o âmbito deste texto. Pergunto de modo bem delicado, como é que profissionalmente tinha sido a sua vida. A forma como a pergunta foi formulada, o termo profissionalmente, bem enquadrado na pergunta, deu-lhe confiança. É ela que agora me olha com ternura, digamos com confiança e com a sua resposta deixou-me pregado ao chão. "Profissionalmente, fiz de tudo. Estamos num país estrangeiro. Ninguém nos conhece, ninguém nos vê, não há ninguém das nossas gentes para me ver, para com isso me envergonharem, para com isso me criticarem". Sublinha com mudança de tom a palavra "ninguém"! De imediato, lembro-me de Sartre, lembro-me de jovens estudantes do meu tempo, muitos deles mais tarde deram líderes políticos, que nos anos sessenta no café Nova Iorque ou no Tatoo, em Lisboa, discutiam existencialismo versus marxismo, lembro-me de uma frase que andava na boca de todos nós: "o inferno são os outros". 
De mediato e de forma simples, encontrei o mesmo sentido mas sem marxismo, sem existencialismo.

"Fiz de tudo", diz-me. Muitas escadas terấo sido lavadas, muitas estufas de morangos apanhadas, muitos campos de feijão-verde colhidos, muitas caixas de tomates encaixotados, muitas carrinhas de transporte de fruta carregadas, muitos horários de trabalho violados, muitos dias de trabalho de 12 horas a 16 horas. Muitas noites de má qualidade, muitas em campos ao luar certamente, enrolada ou náo com quem não sabe quem, numa torre de Babel de ucranianos, russos, moldavos, e pasme-se, de chineses e chinesas, muitos em quartos de oito a dez pessoas, em quartos de cama sempre quente, como na China ou como num prédio perto da rotunda do Hospital de Faro, noites mal passadas por aqui ou algures e caladas pelo silêncio de todos, inclusive pela ignorância sistematicamente assumida das autoridades oficiais. Sobre esta gente, o governo de entáo nada queria saber, o Serviço de Estrangeiros e Fronteiras não se pronunciava, estava só preocupado com os vistos gold, o ministério da Solidariedade, Emprego e Segurança Social tudo ignorou. E o problema é igual por todo o lado. Passa-se o mesmo com estes trabalhadores em Espanha, em França, na Itália e mesmo, até há uns anos atrás na Grécia de antes da crise, com os morangos criados em altitude. Como assinalava o antigo ministro da Agricultura do quinto governo provisório, Oliveira Baptista, como é que dormem as romenas, por exemplo, da apanha do morango, ninguém sabe, ninguém quer saber, também. Gente descartável, a lembrar Bales (2001), gente que a Comissão Europeia, o BCE, o FMI, os diversos governos neoliberais assalta, como verdadeiros espoliadores de quem vive do trabalho precário, mas não na calada da noite, a lembrar o poeta Zeca Afonso, mas sim à luz do dia, munidos quer de um poder que lhes concede a ideologia que as instituiçôes e os interesses produzem e que depois difundem por todos os meios possíveis quer do poder que nem sempre o voto lhes dá, a lembrar Marx também, ele que está cada vez mais atual.

"Fiz de tudo", é a sua expressão. Nas condiçóes em que fez de tudo, meu Deus, muita gente ficou sem trabalho, sem fazer nada, porque simplesmente deste tipo de trabalho os trabalhadores nacionais com direitos são excluídos pelos empregadores e acusados depois pelos neoliberais de hoje e outros de não 
quererem trabalhar, porque o subsídio de desemprego é elevado. Do mesmo são desde há alguns anos acusados os gregos, pelos alemáes! Deslocalização no local, diriam os economistas. Como os terrenos náo podem deslocar-se para onde estão os trabalhadores pretendidos, então são estes que se deslocam, mas com os níveis salariais dos seus países de origem ou muito pouco mais. Relativamente aos trabalhadores nacionais, estes estrangeiros normalmente aceitam outras condiçôes de trabalho bem mais gravosas, mais baratas para os empregadores, até porque ninguém conhecido vê a que se sujeitam. Deslocalização no local feita por trabalho imigrante, sem direitos, muito dele ilegal, tem sido uma realidade no nosso país depois da queda do muro de Berlim, tendo-se sofisticado entretanto os mecanismos de "contratação" deste tipo de mão de obra.

Esta mulher parecia-me alguém da burguesia, da pequena burguesia do seu país. Perguntei-lhe o que fazia na Rússia e respondeu-me que tinha feito muita coisa, foi empresária, teve lojas, trabalhou com a polícia. O seu marido morreu, passou a ser a base da família. Veio a queda de Gorbatchov, tudo se tornou difícil. Emigrou para Espanha. Não gostou e dá-me uma explicaçáo curiosa: "Éramos vistos como escravos, nunca como pessoas. Vim para Portugal, gostei, fiquei. Hoje trabalho numa clínica em Albufeira. Vim a Faro trazer análises a uma clínica. Não percebo. Vir de Albufeira aqui. Economicamente não percebo o vosso sistema de saúde".

Fica-me no ar o sentido apurado que ela tem quanto ao sistema de saúde português, fica-me também presente o termo polícia, fica-me no ar o seu aspeto e o seu andar fisicamente desenvolto. Claramente andar de militar, postura toda ela de militar. Trabalhou com a polícia, relembro.

Fala-me da família. Tem uma filha, dois netos, já viveram em Portugal. Diz-me que percebeu que o neto mais velho no primeiro ciclo em Portugal não aprenderia nada de jeito e que o seu segundo neto poderia ir pelo mesmo caminho. Ficariam como dois ignorantes. E acrescenta: "Disse à minha filha que pagava tudo mas queria-os na Rússia, não queria ter dois ignorantes em casa".

Quando ouço esta afirmação, lembro-me do filme Lisboetas, de Sérgio Tréfaut, lembro-me de uma cena em que na praia uma imigrante de Leste 
comentava e afirmava que o pior que havia em Portugal era o nosso sistema de ensino.

Imagino-lhe os seus seios como duas fontes capazes de dar de beber ao mundo, a todos os nossos filhos e netos em situação de precariedade, vejo-lhe os braços fortes, com a força de quem pode carregar com os meninos deste mundo, sejam Jesus ou outros, vejo-lhe as máos com a garra de quem o futuro dos nossos netos é capaz de embalar, vejo-lhe o dedo indicador apontado para a frente, num ângulo de 45 graus como que a apontar entre o Céu e a Terra, como que a situar-se entre o ter e o náo ter, entre o ser e o não ser, a dizer-me que hoje é essa a sua missão, em frente pois, a de ajudar a criar os seus.

Chego ao quiosque dos jornais, na central de camionagem. Pergunto, por fim: "E se não houver camioneta?" De novo a segurança de quem se sente no seu caminho, a percorrer o seu presente e a caminho do seu futuro, de novo uma resposta para mim inesperada. "Se não houver camioneta, dou uma volta e faço-me à estrada”.

Despeço-me. Vejo-a a seguir para a bilheteira. Vejo-a entáo como uma Maria, a da Rússia, como uma Maria, a de Jerusalém, como uma Maria, a de West Side Story, e sobretudo, mas sobretudo, vejo-a como a Maria, de Fritz Lang, em Metrópolis.

"Fiz de tudo", é o que esta mulher me diz. E foi assim a sua luta pela vida, a luta pelos seus a tudo exigia. Pela sobrevivência, foi isso, é isso também.

Ainda nesse verão, em Faro, li um livro de Shaxson (2012) sobre paraísos fiscais. Por associação e pelo que no livro lia, lembrei-me desta minha "generala" e do trabalho duro que estaria disposta a ter para que os seus netos fossem senhores de um outro sistema certamente, o que era bem explícito na crítica velada aos nossos sistemas de saúde e de educação. E ela, que privilegia a cultura, diz-mo a mim, abertamente, e sem o saber, a um professor universitário que se sente a viver num país onde as Universidades passaram a cultivar a ignorância e a assumir como normalidade os cortes na despesa pública com o ensino superior e que por isso abandonou o ensino antes do tempo face ao descalabro cultural a que estava a assistir e de que náo queria 
ser cúmplice. Mas neste país de que a minha "generala" se queixa do seu ensino, da reforma dita de Bolonha ninguém fala. Pacto de ignorância entre as diversas forças políticas do dito "arco da governação", que foram responsáveis pela sua implantação e manutenção.

Mas a Maria, a da Rússia, ignora a crise ocidental, os mecanismos que a produzem e que tudo arrasam. Hoje, não sei se terá emprego, em Albufeira ou algures, se não lhe terão cortado as remuneraçóes, se o dinheiro a enviar passou a não ser suficiente para formar os seus netos, jovens do futuro, se tudo se lhe tornou ou não ainda mais precário. Ela ignora a crise que é traçada e desenvolvida a partir das cidades onde se dinamiza a crise que as Marias algures combatem, nas Metrópolis do mundo moderno, onde só há agora escravos ou senhores porque os outros, as classes médias, esses só conhecem o caminho socialmente descendente. Talvez não haja melhor descrição dessas cidades do que a dada por Shaxson (2012) a propósito de um dos centros mais importante onde se desenvolve a crise atual, o Principado do Mónaco. Este pré-configura o mundo moderno onde há apenas duas classes: os proprietários de jatos e os que andam de autocarro. Os restantes são considerados suspeitos e suscetíveis de serem presos. Há um polícia por cada 62 habitantes e câmaras de vigilância por todo o lado a fim de o Príncipe Albert - que tudo supervisiona à maneira de um senhor feudal - não ser incomodado. O barulho é o inimigo público número um do Principado ainda mais que o socialismo.

Mas a Maria, a da Rússia, como a maioria das outras Marias também, ignora tudo isto, eu não, nós todos também não. A Troika, a crise, os governos nacionais daquela dependentes diretamente como Portugal, Grécia, Irlanda, Chipre, ou indiretamente como a França, Espanha, Itália, governos nacionais que têm sido os verdadeiros servidores, os verdadeiros intermediários do poder das Metrópolis modernas, bem se encarregaram de conduzir esta precariedade ao nível do nunca pensável por ninguém, nem por nenhuma Maria isoladamente. São precisas muitas Marias mais, a da Rússia, claramente só por si não chega, são precisas todas ou quase todas as Marias do mundo em conjunto para acabar com a situaçáo de desprezo por quem trabalha e por quem tem direito a um trabalho condignamente remunerado e não o tem. 
Dessas vidas de precariedade, há por aí aos milhares. É passar à hora de almoço por uma das estufas que se estendem pelas vizinhanças de Faro e ver as centenas de mulheres de vários países e de diferentes continentes onde só as liga uma língua comum, a do silêncio, uma vivência comum, a da precariedade quase absoluta, um desejo comum, o da sobrevivência.

Estas são histórias sobre imigrantes, mas muitas histórias há também sobre emigrantes ou sobre portugueses que se sentiram forçados a emigrar. E aqui lembro-me de um amigo meu, residente em Faro, marceneiro de vocação e desempregado de profissão.

\section{Portugal a forçar a emigração}

Nesse mesmo ano em que conheci a minha "generala" russa, quando cheguei ao Algarve, falei com um amigo meu, homem de mãos marcadas por obra de classe ao longo de muitos anos na madeira talhada, sobre a situaçáo de crise no mercado de trabalho de gente não muito especializada. "Emprego?" pergunto. A resposta? Nem a esperei, vi-a na cara dele. Perguntei-lhe se já tinha ido ao centro de emprego, direito a subsídio já não tinha. Diz-me que sim, registou-se como candidato a emprego em obras de carpintaria para a construçáo e, pasme-se, ofereceram-lhe sem direito a mais nada como compensação a possibilidade de ir ter aulas, gratuitamente, de alemão. Aulas de alemão para um homem desempregado da construção já com 55 anos e, portanto, sem ouvido para aprender alemão ou uma outra língua do mesmo género. Anedótico. Em Faro, há milhares de homens como o meu amigo sem emprego e há prédios na parte histórica a cair por falta de obras de restauro, há calçadas de pedras soltas ou de buracos onde os velhos vão caindo e fazendo fraturas! $\mathrm{E}$ a estes homens, em vez de trabalho, oferecem-lhes aulas de alemáo, para emigrarem, possivelmente para a Alemanha, a confirmar que o sonho alemáo significa o pesadelo europeu, para abandonarem a sua "zona de conforto", utilizando aqui uma expressáo de um ex-governante! Onde está então a demonstração da afirmação-chave da União Europeia, de Juncker, Draghi, Schäuble, Merkel, de que a austeridade 
traz consigo o crescimento ou a afirmação de Passos Coelho, enquanto primeiro-ministro, de que é preciso empobrecer para depois poder crescer?

Responder a esta pergunta é hoje muito fácil e a resposta está nos resultados económicos até agora obtidos na Europa em crise. Um falhanço total. Não há, pois, dúvida possível. Quando fiz a pergunta a mim mesmo, lembrei-me então do demógrafo catalão de residência Hugh (2012), que pensava que a Portugal, dada a situação económica, só lhe faltava fechar a porta e desligar a luz. Seria o nosso primeiro-ministro de então, Passos Coelho ou algum dos seus ministros, que iriam assim desligar as luzes e trancar as portas e adicionalmente, para maior segurança da sua obra malvada, colocar-lhes múltiplas correntes e cadeados para ninguém as conseguir abrir e voltar a entrar? Uma mão de obra barata, sem direitos e sem Pátria, a vender-se por essa Europa fora, era este um dos resultados desta política, o resultado desta globalização feita a todo o custo e contra todos os direitos de cidadania. Seria pois este o caminho para o estabelecimento do capitalismo global e sem uma governação global, onde o trabalho seria apenas uma variável de ajustamento.

A este nível, a União Europeia com as suas políticas de austeridade, com os seus tratados e a sua arquitetura institucional aparece a reforçar essa mesma dinâmica globalizante e selvagem, afastando-se por isso mesmo dos ideais da Europa dos cidadãos com que muitos de nós sonhámos, ideais que substitui pelo da soberania absoluta dos mercados. Compreende-se, pois, que contrariamente ao Tratado de Roma, a União Europeia seja agora talvez o espaço económico mais desprotegido em termos de mercado mundial. A globalização, primeiro, a proteção aduaneira, depois, quando da indústria e dos serviços que lhe estão ligados pouco já haverá a proteger!

Neste quadro, determinado por um lado pela nossa própria história e, por outro, pela marcha a toda a velocidade para a globalização e a um ritmo acelerado imposto pela própria União Europeia, passámos a ser um país sem futuro, integrados numa Europa também ela já sem horizontes, sem perspetivas, disposta a mergulhar nos mesmos erros que a colocaram no atual atoleiro e a ficar completamente impotente face aos grandes problemas que tem de enfrentar, cansada e exausta, é o que penso. A este propósito, e uma vez mais, lembro-me 
das conversas com o António Gama sobre a Europa de Leste, recordo-me igualmente de Beaudouin (2013) quando este afirma:

Com efeito, a passagem da Europa das naçóes à Europa da integração, do mercado comum à globalização mercantil é a assinatura de uma grande renúncia. Uma renúncia à Europa como vontade e como civilização. Uma renúncia à democracia compreendida como a soberania coletiva e mais geralmente como "o governo dos Homens". Esta renúncia egoísta das novas elites - aquelas que controlam os fluxos de dinheiro e de informação mundiais - conhece grandes precedentes históricos: no século IV, a decadência do espírito público que atingiu a classe dirigente romana provocou a desordem que está na origem da implosão de Roma assim oferecida aos invasores; do mesmo modo, o desmoronamento moral das elites francesas preparou o desmoronamento militar e "a estranha derrota” de maio-junho de 1940, de acordo com a famosa fórmula de Marc Bloch.

Os estados da Europa, em vez de pensarem sobre uma arquitetura europeia flexível numa economia de mercado, que conjugue respeito pelas democracias e pela necessidade de fronteiras, colaram-se uns aos outros sob a égide da administração de Bruxelas, como galinhas doentes, a um canto do galinheiro. Já não era nem a paz nem a fraternidade europeia que os movia desta vez, mas a angústia de um mundo que estava em grande mudança. A integração supranacional é a última viagem das democracias cansadas, exaustas e quase que aliviadas por sentirem estar a chegar o seu fim, sem nenhum problema de consciência face às responsabilidades decididamente exigentes da soberania.

Também eu me sinto cansado, exausto, corroído por esta realidade terrível de que estamos a sofrer. Deambulo pela cidade de Faro. Impressionante, Portugal lentamente está a fechar, penso. Chego ao coração do centro da cidade. Percorro-o até ao fim e é o mesmo desastre. Lojas fechadas e o desastre mantém-se até chegar ao pé do Hotel Faro. Tudo dá a entender que se estão a construir pesadas portas de ferro virtuais de pesados e ferrugentos gonzos nas duas entradas da Rua de Santo António, pulmão comercial de Faro, com o governo de Passos Coelho a informar, saiam, saiam, que as portas vão fechar, fechem as lojas, fechem as casas, fechem os vossos corações, que a maioria já 
se foi embora. Quando saírem oferecemos cursos de alemão, gratuitamente. E, de novo, penso no demógrafo Hugh e no seu artigo.

Em conversas de longas horas com o meu amigo marceneiro um problema relembrei, o de muitos jovens náo terem sequer dinheiro para procurar emprego. Diz-me, veja-me: "A namorada do meu filho concorreu para Lisboa, para um emprego numa multinacional alemá. Entrevista na parte da manhã. Vai daqui, de Faro, de comboio na véspera. Dorme num hotel em Lisboa, tem de ter boa apresentaçáo, e o custo cifra-se bem alto, bem perto dos cento e cinquenta no total". "Ficou doente depois de chegar", diz-me ele. "Se não fosse o meu rapaz não sei como estaria ela hoje, depois daquilo...", “Como é!?” questiono eu. "Não sei explicar bem”, e as palavras atropelam-se-lhe umas nas outras. "Não sabe explicar bem?" O meu amigo é homem de palavras francas, diretas e simples. "Sabe, o pai dela é polícia graduado na reforma, a mãe empregada de limpeza num escritório". "Mas que tem isso a ver com a entrevista na multinacional alemã?” interrogo-me eu. “Tem, tem”, diz-me. "Sabe, para um emprego de engenheiro perguntaram-lhe a profissão do pai, da máe", diz-me com ar de contrariado, “e depois estranhamente disseram-lhe um pouco mais ou menos isto: não entendiam como é que sendo filha de um polícia e de uma mãe empregada de limpeza podia aspirar a um emprego daqueles com tanta gente de origens mais nobres à procura de emprego e numa multinacional de tanto prestígio como aquela”. Percebi. Do meu ponto de vista o problema não era alemão, era de quem fazia a seleção, gente portuguesa de gema, tratava-se da segunda triagem. Terá passado a fase mais difícil da seleção, aquela onde há muitos mais candidatos. A situação confunde o entrevistador da multinacional alemã que chega a disparar: "Não percebo. Sendo tão inteligente porque é que não tirou o curso numa outra Universidade, numa Universidade mais nobre, de Lisboa ou até de Coimbra, por exemplo”. A conclusão é imediata, não se licenciou numa Universidade dita nobre, logo não tem "pergaminhos", logo náo deveria ter passado à segunda fase. Uma piada portanto por ter passado na primeira fase, penso eu, o que de resto se explica pela interrogação que a seguir é bem clara, desse ponto de vista, quando ele repete que não percebe. De facto, ainda acrescenta: "Não 
percebo também porque é que sendo filha de gente tão pobre não foi antes para mulher-polícia”. Gente bem portuguesa e esta jovem, com a sua origem de classe humilde, não daria possibilidades de contrapartidas financeiras ou mesmo políticas, de imediato ou a prazo, mesmo que por debaixo da mesa, penso eu. Ou será que estarei a branquear uma outra coisa? Penso que não estou. "O destino dela é o de um dia ir inscrever-se no centro de emprego e será que também a ela lhe irão oferecer cursos de alemão para garantir o subsídio de desemprego?" pergunta-me ele, com uma certa ansiedade na cara. No fundo, o mais provável é acontecer a esta jovem algarvia o que aconteceu a muitos dos jovens portugueses de elevado nível de formação, ou seja, emigrar e mais provavelmente para a Alemanha. Emigrantes em potência, foi nisso que o governo português sob a égide conjunta de Passos Coelho e da Troika e sob a vigência do memorando do (des)entendimento quis transformar o país. Neste caso, a atingir gente que poderia ascender no elevador social,

gente que é praticamente convidada a sair do nosso país. Portugal paga os custos de formação, os estrangeiros ganham os rendimentos da sua produção. Simples, portanto.

\section{A decomposição a sul e a leste da Europa}

Se tiver em conta que o descrito no ponto anterior também se passa em Espanha, se passa na Irlanda, se passa no Chipre, se passa na Itália, se passa na Grécia e assim sucessivamente percebe-se que a Europa está cheia de gente perdida, migrantes sem destino, já sem raízes, e percebe-se ainda que tragicamente estão também com o futuro capturado pela globalização, sobretudo como consequência das opçóes de política estabelecidas e depois impostas pelas instituiçóes europeias e por Washington também. Veja-se a Ucrânia e as camionetes de polacos que encheram a praça Maidan em Kiev, de que tanto falei com o António Gama, Ucrânia que é hoje uma espinha cravada na Europa, Europa percorrida por fenómenos migratórios que ressoam a desastre profundo neste continente. 
Esta ideia da Europa atual pode ser confirmada a partir de um dos pontos mais problemáticos que a política europeia de austeridade e a política belicista da NATO teráo em conjunto criado, a Grécia, o calvário da gente que sai, o calvário da gente que entra. De novo, a Grécia a ser mais um país atravessado por fortes fluxos de emigrantes, um milhão em cinco anos, e por fortes fluxos de imigrantes, os quais têm sido objeto de reportagens que encheram as páginas dos jornais.

Dos tempos e dos ventos de esperança que à Grécia acostaram em 25 de janeiro de 2015, lembro duas afirmações de Alexis Tsipras. Uma no seu discurso de investidura: "O orgulho e a dignidade do nosso povo não serão postos sobre a mesa das negociaçóes; somos a carne da carne deste povo, somos cada palavra da Constituição deste país e é a ele que serviremos até ao limite". A segunda num discurso ao país, a 3 de julho, antes do referendo: "Domingo, 5 de julho, dirigiremos, todos em conjunto, uma mensagem de democracia e de dignidade à Europa e ao mundo. A Grécia, a nossa pátria, era, é e permanecerá o berço da civilização europeia. É neste lugar, diz a mitologia, que Zeus, retirando-se, conduziu a princesa Europa. E é deste lugar que os tecnocratas da austeridade desejam atualmente retirá-la. Mas não o farão. Porque domingo dir-lhes-emos 'não'”.

Dos tempos e dos ventos de desesperança agora impostos por Bruxelas, Frankfurt e Berlim, apresento uma amostra sobre o que se passa na Grécia. Para o efeito, utilizo um excerto de uma análise de Grigoriou (2015):

[Diz-nos Alexis Tsipras, em setembro de 2015: "Nós conquistaremos o amanhâ". Mas], para os médicos e para os voluntários do Centro Solidário de Ellinikón, o dia de amanhá... é já a morte conjugada no presente.

"O Parlamento Europeu decidiu atribuir ao Centro Solidário de Ellinikón, o 'Prémio do Cidadáo Europeu', em 2015, em reconhecimento da luta que efetuámos desde há quase quatro anos, em benefício dos abandonados pelo Estado oficial, desempregados, doentes sem cobertura da Segurança Social, para enfim ajudar a construir uma sociedade melhor. Esta luta, contudo, foi táo necessária porque, precisamente, as políticas aplicadas e as que se continuam a aplicar no nosso país levaram a excluir do sistema de saúde mais de três milhóes de cidadãos, desempregados, sem abrigo e pobres... 
É então com muita pena que constatamos que a prioridade desta Europa é sobretudo a de encontrar milhares de milhôes de euros para os bancos privados, enquanto pressiona as despesas do sistema nacional de saúde na Grécia, que já se reduziram para menos de metade relativamente ao orçamento de 2009 e que em breve se podem reduzir ainda mais". De acordo com os dados do Instituto Prolepsis, o empobrecimento massivo da maior parte do povo grego já conduziu a uma tragédia: 6 em cada 10 alunos em 64 escolas de Atenas encontram-se numa situação de insegurança alimentar. $61 \%$ dos alunos das mesmas escolas têm já um familiar desempregado, enquanto para $17 \%$ das famílias nenhum familiar tem emprego. $11 \%$ das crianças não têm cobertura da Segurança Social e 7\% de entre elas viveram sem eletricidade durante mais de uma semana durante o ano 2014, enquanto 3\% das crianças continuam ainda a viver sem ela. Em 2014, 406 escolas de toda a Grécia receberam ajuda para alimentar 61.876 alunos. Este ano, 1053 escolas solicitaram esta ajuda a fim de beneficiarem do programa "Alimentação" e assim poderem alimentar os seus 152.397 alunos. Hoje, são apenas 15.520 alunos de 150 escolas que estão a beneficiar deste programa...

Esta Europa entáo que nos quer recompensar parece não se sentir de modo nenhum embaraçada em face de todas estas verdades nem em face das já milhares de mortes de nossos concidadãos excluídos do sistema de saúde. Estes falecimentos teráo entáo em breve um efeito de bola de neve, dado que o terceiro memorando assinado pelo governo impõe reduçôes suplementares no sistema de saúde, de 933 milhóes de euros numa primeira fase.

Seria hipócrita da nossa parte receber este prémio quando esta Europa fecha os olhos aos lactentes que sofrem de desnutriçáo, aos doentes atingidos de cancro já mortos, ao olhar cheio de desespero dos doentes que sofrem, às mães que nos contam as suas histórias terríveis sobre o abandono de que as suas famílias são vítimas, vivendo sem eletricidade, sem água corrente e com um mínimo de alimentos".

Uma vergonha! Ainda de acordo com Grigoriou (2015):

$\mathrm{O}$ tratamento infligido à Grécia faz-nos antecipar o que se irá produzir em Itália, Espanha ou França [ou mesmo em Portugal]. Temos aqui certamente 
cinco anos de avanço sobre o futuro da Europa, o verdadeiro Futuroscópio é imediatamente visitável em Atenas.

Contudo agora sabe-se. A guerra será longa e será sem piedade. Haverá naçôes a revoltarem-se e haverá populaçóes que irăo perecer. As nossas linhas (Maginot) políticas herdadas da época democrática, com todas estas histórias bem caricatas a dormirem de pé antes de morrer entre a "esquerda" e a "direita" e que não pôem em causa o totalitarismo europeísta, estáo neste momento obsoletas.

Mas este etnólogo grego vai mesmo mais longe na sua análise:

Memorando após memorando, suicídio após suicídio, é então a relação... social tecida em torno do medo e da morte que se torna entáo a catalisadora não controlável do futuro. A barreira anatómica da sociedade grega foi aberta desde então, a ferida está escancarada. O medo foi vencido já em janeiro de 2015 e, seguidamente, aquando do recente referendo. Daí muito... logicamente esta expedição punitiva [que é o terceiro memorando, o que Tsipras terá agora de executar], herdada do passado imperial e nazi da elite alemá.

Tudo bem claro, portanto. Desta Europa é pois uma trágica imagem que se acaba de descrever. Os aprendizes de feiticeiros que governam esta Europa em profunda crise têm rapidamente de ser substituídos, demitidos, caso contrário não se sabe que hecatombes mais eles serâo capazes de provocar. Náo basta portanto caírem os funcionários locais, como aconteceu com a queda do governo de Passos Coelho. Parece agora confirmar-se a ideia de George Kennan de que os europeus tinham tanta falta de visão coletiva ou de entendimento mútuo que o Departamento de Estado [americano] teria de "decidir unilateralmente" o que seria bom para eles. Mas os tempos são outros e os Estados Unidos já náo é os Estados Unidos do plano Marshall nem Obama, prémio Nobel da Paz, tinha a força que precisaria de ter, prisioneiro que também ele estava, não de fanáticos protestantes na Europa como Jens Weidmann, a simbolizar o Bundesbank, mas sim de dirigentes do Tea Party, das igrejas dos Estados Unidos profundo quer ainda da estrutura militar americana e do NSA. É pena! No fundo, tudo leva a crer que são estes fanáticos que andaráo a governar o mundo e só assim é que se 
pode entender o conjunto de conflitos que assolam a humanidade, sendo alguns deles, concebidos ou a terem tido a sua origem em decisóes tomadas em Washington, bem perigosos, em risco de levarem a uma terceira guerra mundial. "Quem gerou o monstro Frankenstein?" perguntou no Senado Francês o general Vincent Desportes. E deu a resposta: "Os Estados Unidos" (Senado Francês, 2014). Isto só é logicamente entendível se Obama estivesse prisioneiro das forças reacionárias citadas. No fundo, a dar-nos a ideia de que a agressiva política externa americana é um sub-produto para contornar as dificuldades internas, a confirmar a tese de Alexis de Tocqueville de que, nas democracias, "as políticas externas são frequentemente efetuadas a partir da política interna". Parece ser este o caso, o de Obama como o foi o de Bill Clinton, também. Devido a estas políticas extremamente belicistas, aí estáo os enormes fluxos migratórios vindos do Médio Oriente ou da Europa Oriental e que agora podem mesmo pôr em perigo os delicados equilíbrios que se verificam na União Europeia. E era por aqui que passava também a crítica aguda de António Gama à política imperial americana.

É neste contexto global que deve ser encarada a situação na Grécia. Para se ter uma ideia do impacto possível da emigração grega com destino à Alemanha, também o destino mais provável da nossa jovem algarvia acima referida, basta uma notícia da imprensa local a respeito dos jovens gregos de elevada formação, segundo a qual mais de dez mil engenheiros deixaram o país ao longo de cinco anos, de acordo com as estatísticas do organismo profissional que os representa. Um país a esvaziar-se de gente com qualidade, de gente a emigrar, um país a precarizar-se cada vez mais por essa via e, drama maior ainda, é agora um país a ser arrasado pela imigraçáo em massa, ao encher-se de gente imigrante, vinda de África ou do Médio Oriente devido a políticas a que são completamente alheios e que foram desenhadas a partir de Washington. Uma outra fonte de precariedade, portanto. 


\section{Em jeito de conclusão}

Tempo de imigraçóes, tempo de emigraçóes, tempo de deslocaçóes de populaçóes em massa, na Europa. Os temas preferidos nas minhas conversas com o António Gama. Temas que estaria provavelmente a estudar, a descorticar, a explicar, com a mesma intensidade, a mesma alegria, o mesmo brilho nos olhos com que me explicava a política absurda seguida por Madeleine Albrigth nos Balcâs, cujos efeitos estâo hoje bem presentes, mas agora como problemas europeus.

Bem me poderia também explicar que a trajetória de Albright a Kerry, de Clinton até ao fim do mandato de Obama, é toda ela uma trajetória pura e simplesmente imperial. Nada mais do que isso. Estes seriam, pois, os temas que hoje poderia voltar a discutir com o António Gama e assim problematizarmos todas estas questôes no quadro de uma perspetiva global, se...

A enorme estima vivida entre nós, entre o António Gama e eu, e as lembranças levantadas pela leitura do artigo de Ahmed (2015) acima citado levaram-me, pois, a aceitar escrever um texto para o homenagear, homenagear assim um amigo, um professor universitário que a doença retirou muito cedo do convívio com os seus amigos e eliminou também esta relação especial havida para com a Universidade de que não vestia a "farda", porque a tinha por dentro de si mesmo, no coraçáo e no cérebro como homem de ciência que era. Disto são uma demonstração o seu empenho na problemática da história dos povos, na explicação sobre as grandes ruturas da história e as problemáticas sociais que estas implicavam, o seu empenho na busca das razóes objetivas que lhes estáo na base, por vezes escondidas até por detrás da opacidade com que a realidade historicamente é apresentada, o seu empenho, em suma, em descortinar o real, histórico ou presente, para querer agarrar o futuro a partir de quase já amanhá. Um homem de ciência, de humanidades, portanto, com quem muito também aprendi e que náo quero esquecer. E como me escreveu uma amiga comum: "Do António Gama fica sempre aquela subtil sensação de que ele ainda está entre nós, tal a força da amizade e a força intelectual que ele nos comunicava a todos". Mas não se pode deixar de sublinhar igualmente 
que se vive apenas ou sobretudo um tempo de vazios coletivos, de vazio sobre

o passado, sobre o presente, sobre o futuro, e tempo de vazio deixado pelo António Gama também ${ }^{1}$.

E, com isto, tudo dito.

\section{Referências bibliográficas}

Ahmed, Nafeez (2015). Islamic State is the cancer of modern capitalism, http://www.middleeasteye. net/columns/cancer-modern-capitalism-1323585268, 27 de março.

Bales, Kevin (2001). Gente descartável: a nova escravatura na economia global. Lisboa: Caminho.

Beaudouin, Christophe (2013). La France n'est peut-être pas encore bien consciente qu'elle peut mourir. Nouvelles de France, 22 de outubro.

Grigoriou, Panagiotis (2015). Mensonge et barbarie, http://www.greekcrisis.fr/2015/09/Fr0464. html\#deb, 16 de setembro.

Hugh, Edward (2012). Portugal - Please turn the lights off when you leave!, http://www.economonitor. com/edwardhugh/2012/07/14/portugal-please-switch-the-lights-off-when-you-leave/\#sthash.8adAWvq9.dpuf, 14 de julho.

Senado Francês (2014). Débat en séance publique sur la prolongation de l'opération Chammal en Irak, Audition du Général de division Vincent Desportes, http://www.senat.fr/compte-rendu-commissions/20141215/etr.html, 17 de dezembro.

Shaxson, Nicholas (2012). Les Paradis fiscaux: Enquête sur les ravages de la finance néolibérale. Paris: Editions Andre Versaille.

\footnotetext{
${ }^{1}$ Agradeço a Margarida Antunes a leitura atenta feita a este texto e as sugestōes que sobre ele me foram dadas. Reduzir a dimensão de um texto mantendo o que nele é fundamental nem sempre é fácil e pressupốe um conhecimento profundo do que nele se escreveu. Em tempo de vazios, de vazio de reconhecimento do outro igualmente, este reconhecimento lhe devo.
} 